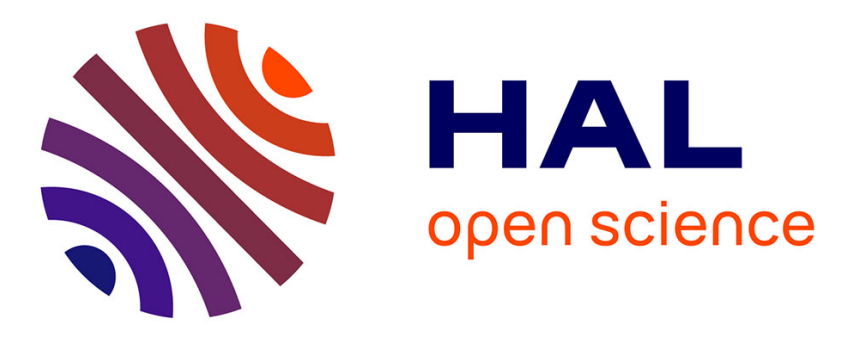

\title{
Phytolith evidence of cereal processing in the Danube Delta during the Chalcolithic period
}

\author{
Mihaela Danu, Erwan Messager, Jean-Michel Carozza, Laurent Carozza, \\ Laurent Bouby, Sylvie Philibert, Patricia C. Anderson, Albane \\ Burens-Carozza, Cristian Micu
}

\section{To cite this version:}

Mihaela Danu, Erwan Messager, Jean-Michel Carozza, Laurent Carozza, Laurent Bouby, et al.. Phytolith evidence of cereal processing in the Danube Delta during the Chalcolithic period. Quaternary International, 2018, 10.1016/j.quaint.2018.03.033 . hal-01992854

\section{HAL Id: hal-01992854 \\ https://hal-univ-tlse2.archives-ouvertes.fr/hal-01992854}

Submitted on 19 Nov 2020

HAL is a multi-disciplinary open access archive for the deposit and dissemination of scientific research documents, whether they are published or not. The documents may come from teaching and research institutions in France or abroad, or from public or private research centers.
L'archive ouverte pluridisciplinaire HAL, est destinée au dépôt et à la diffusion de documents scientifiques de niveau recherche, publiés ou non, émanant des établissements d'enseignement et de recherche français ou étrangers, des laboratoires publics ou privés. 


\title{
Phytolith evidence of cereal processing in the Danube Delta during the Chalcolithic period
}

\author{
Mihaela Danu $^{\mathrm{a}, *}$, Erwan Messager ${ }^{\mathrm{b}, \mathrm{c}}$, Jean-Michel Carozza ${ }^{\mathrm{d}, \mathrm{e}}$, Laurent Carozza ${ }^{\mathrm{e}}$, Laurent Bouby ${ }^{\mathrm{f}}$, \\ Sylvie Philibert ${ }^{\mathrm{g}}$, Patricia Anderson ${ }^{\mathrm{c}}$, Albane Burens ${ }^{\mathrm{e}}$, Cristian $\mathrm{Micu}^{\mathrm{h}}$ \\ a Alexandru Ioan Cuza University of Iaşi, Faculty of Biology, Research Department, 20A Carol I Blv, 700505 Iaşi, Romania \\ ${ }^{\mathrm{b}}$ UMR 5204 EDYTEM CNRS, Université Savoie Mont Blanc, France \\ ${ }^{\mathrm{C}}$ UMR 7264 CEPAM CNRS, Université Côte d'Azur, France \\ d UMR 7266 LIENSS CNRS, Université de La Rochelle, France \\ e UMR 5602 GEODE, CNRS, Université Toulouse, Jean Jaurès Maison de La Recherche, France \\ ${ }^{\mathrm{f}}$ UMR 5554 ISEM CNRS, Université Montpellier II, France \\ ${ }^{g}$ UMR 5608 TRACES, Université Toulouse, Jean Jaurès Maison de La Recherche, France \\ ${ }^{\mathrm{h}}$ Eco-Museal Research Institute, Gloriei Street, Independence Monument Park, 820009 Tulcea, Romania
}

\section{A R T I C L E I N F O}

\section{Keywords:}

Danube Delta

Chalcolithic

Phytoliths

Cereals processing

\begin{abstract}
A B S T R A C T
Recent excavations at Taraschina, south-eastern Romania, have revealed an extensive Chalcolithic settlement in the heart of the Danube Delta. Based on ceramic data, Taraschina was attributed to the Gumelnița Culture and dated to the mid 5th millennium BC by radiocarbon dating. Phytolith analysis was conducted at Taraschina in order to reconstruct some activities carried out by the Chalcolithic populations in the Danube Delta. The study was undertaken on the site sediments, as well as on additional deposits sampled around the site by coring. The results show that phytoliths characterizing cereal processing are attested in archaeological deposits, as well as in the surrounding sequence. Our study highlights an important signal of cereal processing in the heart of the Danube Delta, 6000 years ago.
\end{abstract}

\section{Introduction}

The Danube Delta biosphere reservation is a unique and original research area for the understanding of the interactions between societies and their environment, from prehistoric to present times. The Danube Delta is, due to its area $\left(5165 \mathrm{~km}^{2}\right)$, one of the most extensive wetland areas of Europe. Far from this image of a natural protected area, the Danube Delta is inhabited by about 15000 residents distributed in 15 communities. While multiple studies are dedicated to geographical, geomorphological and geological aspects of the Delta area (Antipa, 1915, 1941; Vâlsan, 1934; Brătescu, 1942; Coteţ, 1960; Ghenea and Mihăilescu, 1981; Liteanu et al., 1961; Panin, 2004; Giosan et al., 2006; Romanescu, 2013; Vespremeanu-Stroe et al., 2017), the impact of past human occupation on the Delta's environment is still poorly documented. Archaeological research (Micu, 2004; Dimitriu, 2012) has identified a limited number of sites within the Delta area, drawing an incomplete history of human occupation. This vast wetland is not easy to survey and the idea that it was not a suitable place for preand proto-historic settlement is widespread (Carozza et al., 2011a). The discovery of two Chalcolithic sites, at Taraschina (Micu et al., 2009;
Carozza et al., 2011a, 2012) and Dâmbul (Mihail et al., 2014), provides indisputable evidence that the Delta was inhabited at least 6500 years ago. The Dâmbul site is too deeply buried and will probably never be excavated, but the Taraschina site has yielded many domestic dwellings recognized both by excavation and coring. The Chalcolithic inhabitants of Taraschina probably preferred such a strategic place to settle, favorable for both control of the region and navigation (Carozza et al., 2011b, 2012). Which kind of activities did these Chalcolithic populations practice in this area? What was the surrounding environment of the site and how did populations manage it at that time? In such a context, it is very important to find out, which characteristics defined the landscape at that time. Among the botanical proxies, phytoliths have proved to be well-preserved in the archaeological deposits as well as in the natural deposits in the Taraschina vicinity (pollen grains were not preserved in any of analysed samples). So far, palaeo-palynological studies have been carried out on surface sea-bed samples from the north-western part of the Black Sea, in order to obtain some data on the distribution patterns of palynomorphs along transects from the Danube River delta front to the outer shelf off the delta (Mudie et al., 2015). But for Danube Delta itself, paleo-palynological data are rare because of

\footnotetext{
* Corresponding author.

E-mail address: danum2007@yahoo.com (M. Danu).
} 


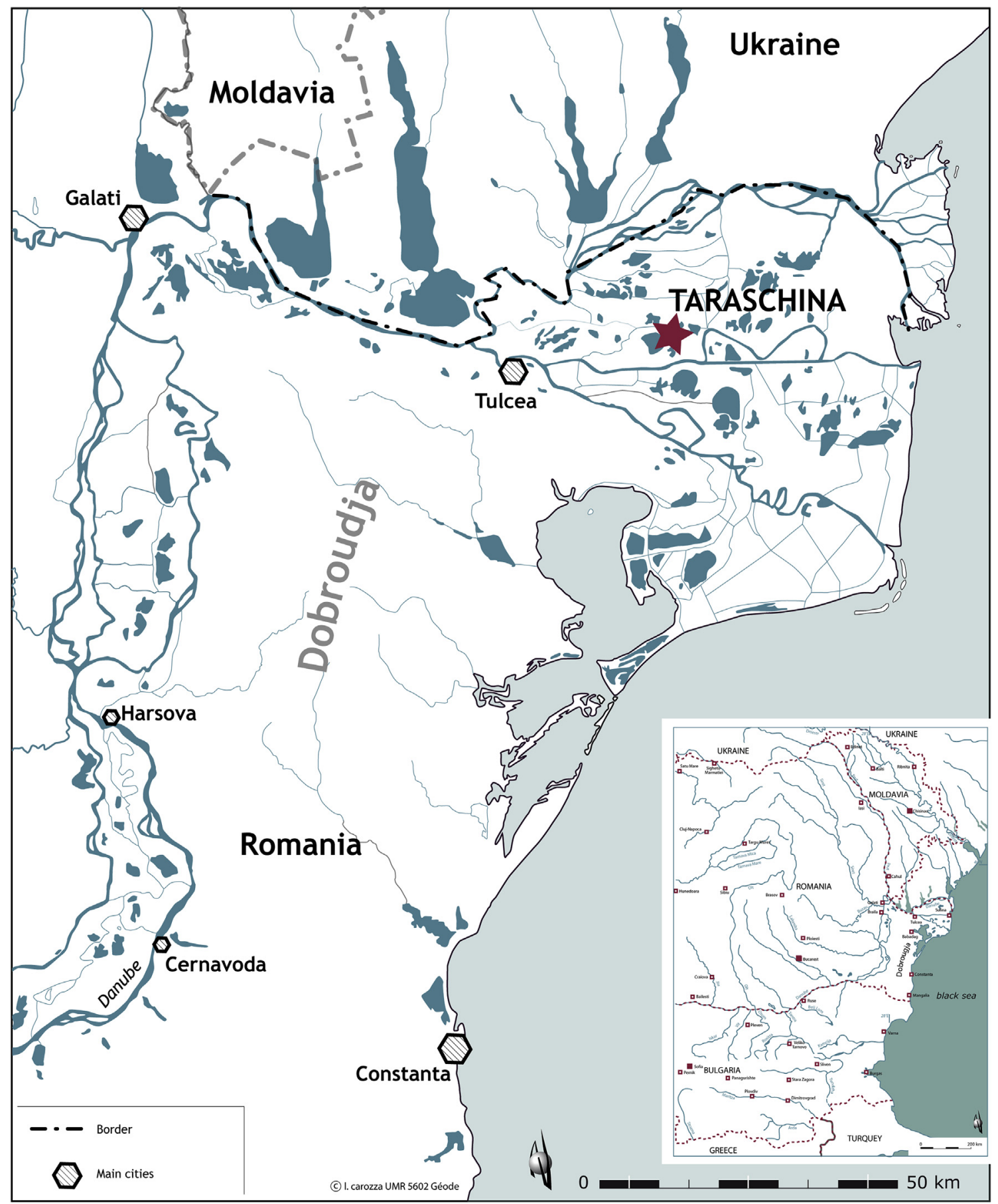

Fig. 1. Map showing the location of Taraschina.

poor pollen preservation. However, since the Bronze Age, pollen results record a mixed deciduous forest dominated by Quercus, Fagus, Carpinus, Tilia. Poaceae pollen dominates, suggesting the presence of a large reed formation (Carozza et al., 2016). This study represents the first phytolith analysis in the Danube Delta. Although the data are preliminary, this study provides information on the subsistence activities of the Chalcolithic communities established in the Danube Delta.

\section{Study area}

\subsection{The Taraschina site and its setting}

The Taraschina site is located within the present day Danube Delta, close to the Mila 23 village, about $23 \mathrm{~km}$ upstream from the mouth of the Soulina (Fig. 1). The exceptional nature of the Taraschina site is mostly due to its position in the Danube Delta. Based on ceramic data, the Taraschina site is attributed to the Gumelniţa Culture (Chalcolithic), and was dated to the mid 5th millennium $\mathrm{BC}$ by radiocarbon dating. The previous oldest archaeological occupation in the alluvial context of the Danube Delta was attributed to the transition period between the Chalcolithic and the Bronze Age (Vasiliu, 1995).

According to preliminary GPS cartography, Taraschina extends over more than $15000 \mathrm{~m}^{2}$ and is composed of at least two main sites (Sites 1 and 2 in Fig. 2). They are composed of several destroyed buildings, associated with many pits.

From a geomorphological perspective, this part of the delta 


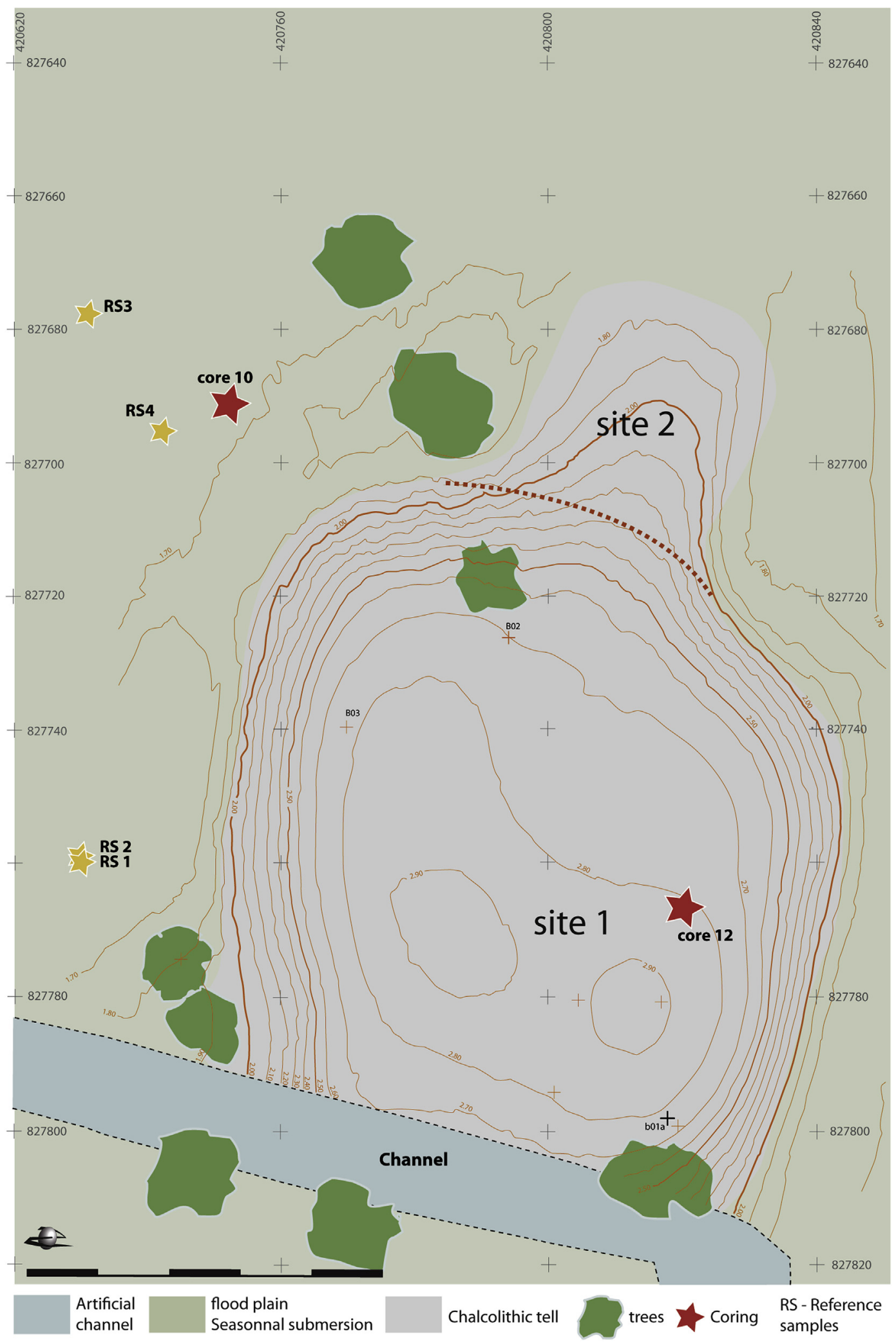

Fig. 2. Location of cores investigated in the site area.

corresponds to the upper and older part of the deltaic system also called "bloqued delta" (Panin, 1972, i.e. a bayhead delta), up to the LeteaCaraorman initial spit, the most prominent geomorphological structure of the delta. The bay-head delta forms a triangular shaped area, bounded in the north by the Chilia arm and in the south by the Sulina Sfântul Gheorghe arm. In the Taraschina area, the number of lakes is reduced, in comparison with other Delta areas. The coring undertaken in the Taraschina vicinity has reached the loess terrace around $4 \mathrm{~m}$ below the surface. The Holocene alluvial sequence, which partially overlaid the site, is composed principally of silts and organic clays. Coarse sediments (i.e. fine and coarse sands) are rare and were only found in the northern part of the site. Palaeogeographic reconstruction 
shows that the site is probably located on the edge of an approximately $2 \mathrm{~m}$ slope (slope terrace or fluvial incision) that overlooks a backswamp zone (Fig. 2).

\subsection{Site occupation}

The chronology of site occupation deduced from analysis of the tell levels, covers a period ranging from 4800 to $4300 \mathrm{cal}$. BC (Carozza et al., 2011a, 2011b). These habitats are mainly related to the culture of Gumelniţa. Archaeological evidence indicates that the site was gradually abandoned, around $4350-4250 \mathrm{cal}$. BC, probably due to a change of function (temporary or specialized habitat). However, the top of the sequence shows that the tell occupations continue between 4300 and $4050 \mathrm{cal}$. BC. For now, no occupation has been brought to light after 4100-4050 cal. BC.

\section{Materials and method}

\subsection{Coring, core description and dating}

In this study, two sequences will be presented (Fig. 2): core 12, extracted on the tell, and core 10, in the direct vicinity of the tell. Both cores were taken using a Cobra TT percussion device. The sequences
Table 1

List of AMS 14C dates from Taraschina cores. 14C ages were calibrated using INTCAL09 (Stuiver and Reimer, 1993; Reimer et al., 2009).

\begin{tabular}{lllll}
\hline Lab. Code & Sample & Type & $\begin{array}{l}\text { Radiocarbon Age } \\
\text { BP }\end{array}$ & Age cal BC \\
\hline $\begin{array}{l}\text { Beta-350 741 } \\
\text { Poz-42867 }\end{array}$ & $\begin{array}{l}\text { Core } 12(-256 \mathrm{~cm}) \\
\text { Core } 10(-158- \\
160 \mathrm{~cm})\end{array}$ & $\begin{array}{l}\text { charcoal } \\
\text { charcoal }\end{array}$ & $\begin{array}{l}5680 \pm 30 \mathrm{BP} \\
5390 \pm 80 \mathrm{BP}\end{array}$ & $\begin{array}{l}4590-4453 \\
4366-3997\end{array}$ \\
Poz-42868 & $\begin{array}{l}\text { Core } 10(-190- \\
192 \mathrm{~cm})\end{array}$ & charcoal & $5600 \pm 40 \mathrm{BP}$ & $4504-4351$ \\
Poz-40109 & $\begin{array}{l}\text { Core } 10 \\
(-223 \mathrm{~cm})\end{array}$ & charcoal & $5470 \pm 40 \mathrm{BP}$ & $4442-4240$ \\
Poz-40109 & $\begin{array}{l}\text { Core } 10(-244- \\
246 \mathrm{~cm}) \\
\text { Core } 10 \\
(-267 \mathrm{~cm})\end{array}$ & charcoal & $5610 \pm 40 \mathrm{BP}$ & $4520-4356$ \\
Poz-40110 & $\begin{array}{l}\text { Core } 10 \\
(-294 \mathrm{~cm})\end{array}$ & charcoal & $5580 \pm 40 \mathrm{BP}$ & $4488-4347$ \\
Poz-40111 & charcoal & $5660 \pm 40 \mathrm{BP}$ & $4592-4370$ \\
\hline
\end{tabular}

were correlated by a number of distinct sediment layers. The lithology of the sequences and available radiocarbon dates are presented in Fig. 3 and Table 1.

In addition, 4 surface soil samples (RS $-1 \mathrm{~cm}$ depth, RS2 $-3 \mathrm{~cm}$ depth, RS3 and RS4 $-15 \mathrm{~cm}$ depth) were also taken from the wetland
Core 12

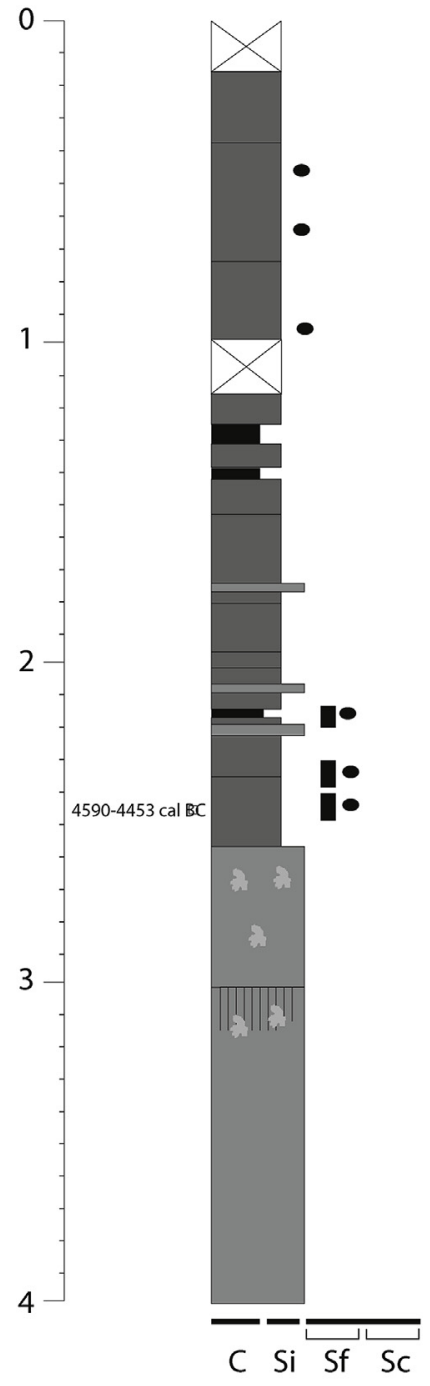

Core 10

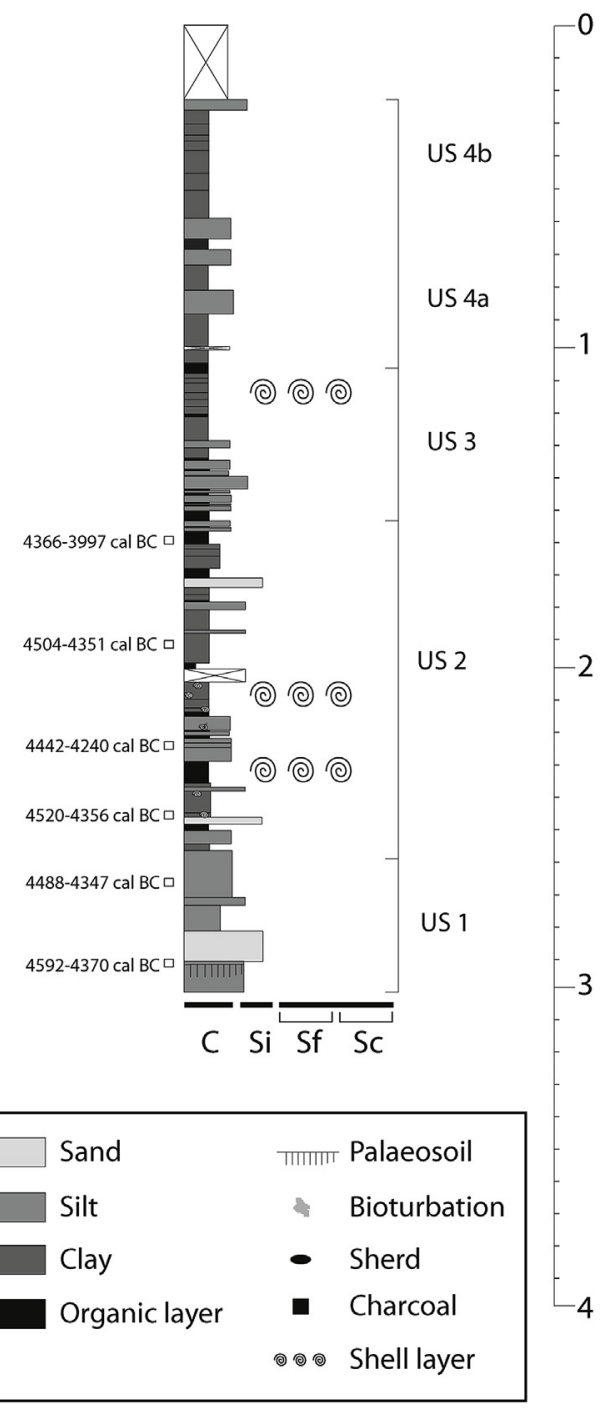

Fig. 3. Stratigraphy of sequences and available radiocarbon dates. 
surrounding the site (Fig. 2) to ensure the comparison with fossil phytolith records.

Core 12. It was directly extracted from the tell of Taraschina, into the excavation zone 1 . The sequence is composed of $4 \mathrm{~m}$ of deposits (Fig. 3). The base of the sequence, from 400 to $319 \mathrm{~cm}$, corresponds to the loessic substratum. At $310 \mathrm{~cm}$, a brown silty level (soil?) was observed. Another silty brown layer is recorded between 249 and $254 \mathrm{~cm}$. Small charcoals from this level $(256 \mathrm{~cm})$ have been dated $(5680 \pm 30$ $\mathrm{BP}$, from 4590 to $4453 \mathrm{cal}$. BC). The middle part of the sequence $(249-119 \mathrm{~cm})$ shows alternating layers of burned and unburned materials, interpreted as buildings, with destruction and re-building phases (Carozza et al., 2011a). This pattern reflects the building dynamic of the tell. The upper part of the sequence (from 100 to $20 \mathrm{~cm}$ ) is composed of a thick silty layer without clear subdivisions. The carbonates present in this deposit are due to recent oscillation of the groundwater table level. In this upper part of the sequence, the initial archaeological layer has been modified by present-day pedogenetic processes and all sedimentary structures of both natural and artificial origine have been removed by bioturbation (roots, fauna activity) and leaching.

Core 10. Sedimentological analysis has been focused on core 10, on which laser grain-size (Coulter Beckman 200), geochemical (XRF, AVAATECH) analyses and Magnetic Susceptibility (Bartington MS2E) have been carried out (Carozza et al., 2013). This core (Fig. 3) can be subdivided into four main units (see Carozza et al., 2013): 1) from 300 to $259 \mathrm{~cm}$ (US1), fine pale brown sediments of massive structure that were interpreted as loess and palaeosoil developed on loess; from 259 to $153 \mathrm{~cm}$ (US2), alternated dark silt and clay were interpreted as fluviolacustrine deposits, consistent with the faunal remains (shells and fishbones); from 153 to $108 \mathrm{~cm}$ (US3), the deposit is a more homogeneous clay-silt organic layer; the top of the core (US4a and b) is composed of an alternation of clay-silt and sandy levels, indicating a fluvial (and more dynamic) origin.

\subsection{Sampling, phytolith extraction, counting and classification}

47 and 17 samples were collected from sequences 10 and 12 respectively for phytolith analysis. Sequence 10 was more sampled and analysed due to its proximity to the Taraschina settlement and its abundant data (radiocarbon dates and sediment analysis). 4 surface soil samples collected from the wetland surrounding the site were taken between 1 and $15 \mathrm{~cm}$ deep.

Phytoliths were extracted from sediment samples using a method adapted from techniques described by Lentfer and Boyd (1998). Carbonates were dissolved in an $\mathrm{HCl}$ bath and organic matter was removed with a $15 \% \mathrm{H}_{2} \mathrm{O}_{2}$ solution heated at $60{ }^{\circ} \mathrm{C}$ until reaction ceased. A $200 \mu \mathrm{m}$ mesh sieve was then used to recover fine particles. Most of the clay particles were removed through decantation and centrifugation after shaking with $15 \%$ sodium hexametaphosphate. Densimetric separation of phytoliths $(\mathrm{d}<2.3)$ from the quartz and other mineral particles was achieved using a heavy liquid solution (Sodium Polytungstate, with $d=2.35$ ). After cleaning, the residue was suspended in Zeiss immersion oil for mounting on glass slides. The slides were observed under a "Leica DMRB ${ }^{\mathrm{m}}$ " Microscope at $650 \times$ magnification. Each phytolith was classified according to its morphology, following several systems (Twiss et al., 1969; Mulholland, 1989; Fredlund and Tieszen, 1994) and the International Code for Phytolith Nomenclature (ICPN Working Group et al., 2005).

The observed phytoliths are classified into 15 different categories. The classes of elongate (Fig. 4 a), elongate dendritic (Fig. 4 b), acicular hair cell 1 (Fig. 4 c), and bulliform (Fig. 4 d) are essentially formed in the epidermis of grasses (Twiss et al., 1969; Piperno, 1988; Mulholland, 1989; Fredlund and Tieszen, 1994), but they can also be produced by other groups (Piperno, 1988; Strömberg, 2002). Cylindric sulcate type (Fig. 4 e) is usually assigned to herbaceous or woody dicotyledonous, but can also be produced in small amounts by conifers and ferns (Piperno, 1988; Runge, 1999). Acicular hair cell 2 (Fig. 4 f) includes atypical trichome phytoliths, but has no taxonomic value because it can be produced by grasses and non-grasses. Classes rondel (Fig. $4 \mathrm{~g}$ ), trapeziform sinuate (Fig. 4 h), bilobate (Fig. 4 i), cylindrical polylobate (Fig. 4 j) and saddle (Fig. 4 k) are produced in epidermal short cells of grasses. They can be used to identify the main Poaceae subfamilies recorded in the phytolith assemblage (Twiss et al., 1969; Fredlund and Tieszen, 1994). Rondels are frequently associated with the Pooideae subfamily (Mulholland, 1989; Piperno and Pearsall, 1998), but are also found in other Poaceae subfamilies such as the Arundinoideae (Barboni and Bremond, 2009). The trapeziform sinuate morphotype can be considered as a good tracer of the Pooideae subfamily (Barboni et al., 2007). The bilobate morphotypes mainly occur in the Panicoideae and Arundinoideae subfamilies. The saddle morphotype is produced in high proportion by the Chloridoideae. Papillae type (Fig. 4 l) corresponds to silicified epidermal papillae, essentially occurring in the inflorescences of Poaceae (Ball et al., 2001; Berlin et al., 2003). Globular phytoliths (Fig. $4 \mathrm{~m}$ ) correspond to the various circular and spheroid morphotypes already recognized and considered as characteristic of the dicotyledonous group (Bozarth, 1992; Alexandre et al., 1997; Albert et al., 1999; Runge, 1999; Delhon et al., 2003). Blocky (Fig. 4 n) morphology is not well identified in our study. In previous work, this class has been assigned to Artemisia or to different Pinaceae genera (Pearsall and Piperno, 1993; Blinnikov et al., 2002). Silica skeletons (linked phytoliths, Fig. 4 o, p) corresponding to fragments of silicified Poaceae epidermis were also identified (Rosen, 1992). They represent the remains of fragmented pieces of culms, leaves and inflorescences of Poaceae plants. Among this group, two classes have been separated "silica skeletons with elongate dendritic" (Fig. 4 o) coming from inflorescences and "silica skeletons with elongate" coming from culm and leaves (Fig. 4 p). Many sponge spicules (Fig. 4 q) and diatoms (Fig. 4 r) were observed, especially in the upper parts of sections. Each morphotype's relative abundance was calculated as a percentage of the sum of classified phytoliths. This sum used for percentage calculations was based on the total number of phytoliths counted per sample (more than 200 for each sample). The silica skeletons, diatoms and sponge spicules were excluded from the total phytolith sum to avoid overrepresentation of these groups. The representation of each of these groups was expressed as percentages of the sum of phytoliths plus the group sum [i.e. $\%$ of diatoms $=\mathrm{N}$ diatoms $/(\Sigma$ phytoliths $+\mathrm{N}$ diatoms $) \times 100]$.

\section{Results}

Phytoliths are very well preserved in the archaeological sequence (core 12), as well as in the "off-site" sequence extracted around the site (core 10). Grasses (Poaceae) are the dominant taxon in all phytolith samples. Among this group, Pooideae (represented by trapeziform sinuate and a part of rondel classes) is the best recorded sub-family (Figs. 5 and 6). Pooideae is the main group of Poaceae in temperate areas, but we cannot exclude that a part of the rondel could be from Arundinoideae (i.e. Phragmites). Globular morphotypes were rarely identified.

Phytoliths were not found in samples below $250 \mathrm{~cm}$ depth (core 12), respectively $290 \mathrm{~cm}$ depth (core 10 ).

\subsection{Phytolith assemblages from core 12}

In the seventeen phytolith samples from core 12 (Fig. 5), the most common short cell type phytoliths are rondel and trapeziform sinuate. Bilobate phytoliths were frequently recorded in the lower part of the sequence (up to $200 \mathrm{~cm}$ ), demonstrating the potential occurrence of Panicoideae or Arundinoideae subfamilies.

Elongate dendritic forms, coming from inflorescences (glumes, lemma, palea) of Poaceae (Ball et al., 2001), are well-represented throughout the entire sequence studied from the site. High proportion (up to $25 \%$ ) of elongate dendritic phytoliths can be observed from 211 to $150 \mathrm{~cm}$. 


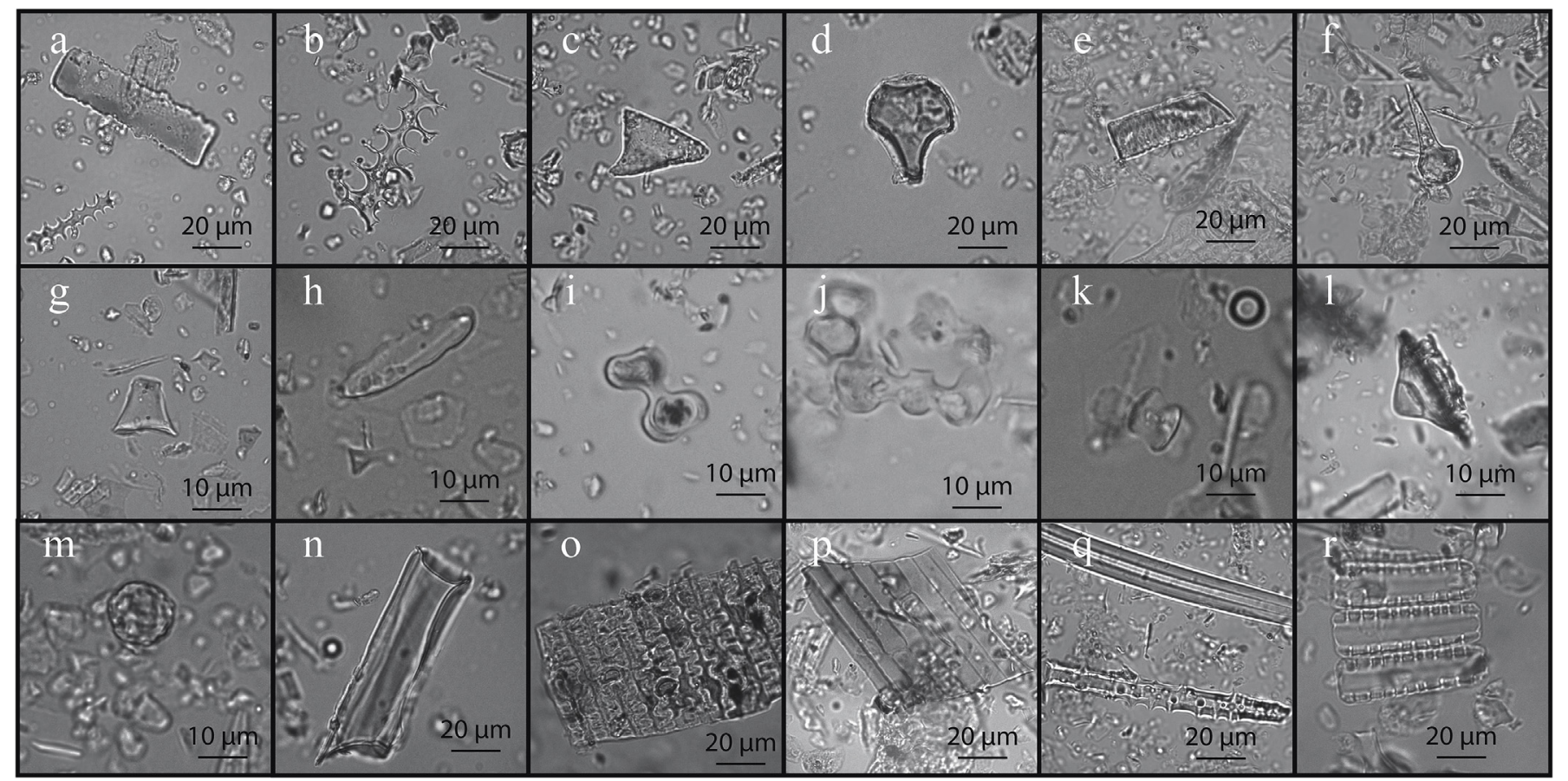

Fig. 4. Pictures of phytolith morphotypes identified in Taraschina sequences: a. Elongate, b. Elongate dendritic, c. Acicular hair cell 1, d. Bulliform, e. Cylindric sulcate, f. Acicular hair cell 2, g. Rondel, h. Trapeziform sinuate, i. Bilobate, j. Cylindrical polylobate, k. Saddle, 1. Papillae, m. Globular, n. Blocky, o. Silica skeletons (with elongate dendritic), p. Silica skeletons (with elongate), q. Spicules, r. Diatoms.

Another interesting feature of these assemblages is the frequent occurrence of silica skeletons (Fig. 5). These fragmented epidermal cells are rarely observed (most of time absent) in natural assemblages. This class of linked phytoliths is particularly significant (over 25\%) in the middle part of the sequence (from 190 to $123 \mathrm{~cm}$ ), displaying the same trend as for the dendritic phytoliths. All samples contain silica skeletons coming from the inflorescence (Fig. 5, those in dark blue color), which are better represented from 180 to $123 \mathrm{~cm}$ (i.e. up to 43 silica skeletons coming from the inflorescence, which means over $59 \%$ of silica skeletons registered at $150 \mathrm{~cm}$ depth sample).

\subsection{Phytolith assemblages from core 10}

Phytoliths are very well preserved in all samples of core 10 . The assemblages recovered in core 10 are quite similar to the assemblages coming from core 12 (Fig. 6). The most common form is the rondel, and relatively high percentages of trapeziform sinuate are recorded (from $37.55 \%$ to $81.67 \%$, except the sample from $68 \mathrm{~cm}$ depth where trapeziform sinuate represented $10.76 \%$ ), highlighting the importance of the Pooideae group. Bilobate phytoliths are frequent in the lower part of the sequence (below $250 \mathrm{~cm}$, in $77 \%$ of samples).

Elongate dendritic forms are very well-represented in the lower and middle parts of the sequence (up to $37.95 \%$ ). Significant values of silica skeletons have also been recorded (i.e. over $22 \%$ at $253 \mathrm{~cm}$ deph). Among this group, linked phytoliths from culms and leaves are better represented $(76 \%-100 \%)$ than those coming from inflorescences (Fig. 6).

Based on variations of the main phytolith morphotypes observed in the sequence (Fig. 6), three zones can be identified in the diagram:

-Zone 1 (Z1: $289-255 \mathrm{~cm}$ ) is characterized by the abundance of elongate dendritic forms (10-20\%) and the presence of silica skeletons (5-10\%).

-Zone 2 (Z2: $254-88 \mathrm{~cm})$ represents the same phytolith assemblage as zone 1, but the silica skeletons are twice as abundant (10-20\%).

-Zone $3(\mathrm{Z3}: 87-50 \mathrm{~cm})$ shows a decrease in dendritic forms and silica skeletons, with an increase in elongate and bulliform phytoliths. From a depth of $78 \mathrm{~cm}$ to the top, there is a huge increase in sponge spicules (from $11.37 \%$ at $78 \mathrm{~cm}$ depth to $43.96 \%$ at $68 \mathrm{~cm}$ depth) and a decline in dendritic and silica skeleton values (less than $2.5 \%)$.

\subsection{Samples references}

All modern soil phytolith assemblages contained large quantities of rondels (Fig. 7) (from $33.33 \%$ to $80 \%$ ). Only a few dendritic forms and silica skeletons are recorded in two reference samples (RS1 and RS2) $(1.53 \%-3.17 \%)$. Bulliforms have also been observed. What is interesting is the overwhelming presence (up to $80 \%$ ) of aquatic environment markers (spicules and diatoms) in all samples (Fig. 7).

\section{Discussion}

\subsection{Implications of phytolith assemblages recorded on the site}

The whole site sequence (core 12) is characterized by large percentages of elongate dendritic phytoliths (up to 25.68\%). While this class of phytolith is scarcely recorded in natural soil assemblages (Novello and Barboni, 2015), such as those coming from the modern reed formation (see reference samples, Fig. 7), it might be very wellrepresented in archaeological sites in which cereals have been processed (Berlin et al., 2003; Portillo and Albert, 2011). Thus, the presence of many dendritic phytoliths is taken as evidence for the presence of cereals at the Taraschina site. The abundance of silica skeletons coming from the cereal inflorescence confirms the presence of cereals in the site. Moreover, the percentages of silica skeletons coming from culms and leaves of Poaceae reflect an accumulation of threshing remains, especially in the middle part of sequence 12 . This phytolith signal gives evidence for cereal processing on the site, or in the immediate vicinity.

The consumption of cereals is also attested in Taraschina by carbonized seeds and fruits. Most of these are cereal grains, especially 


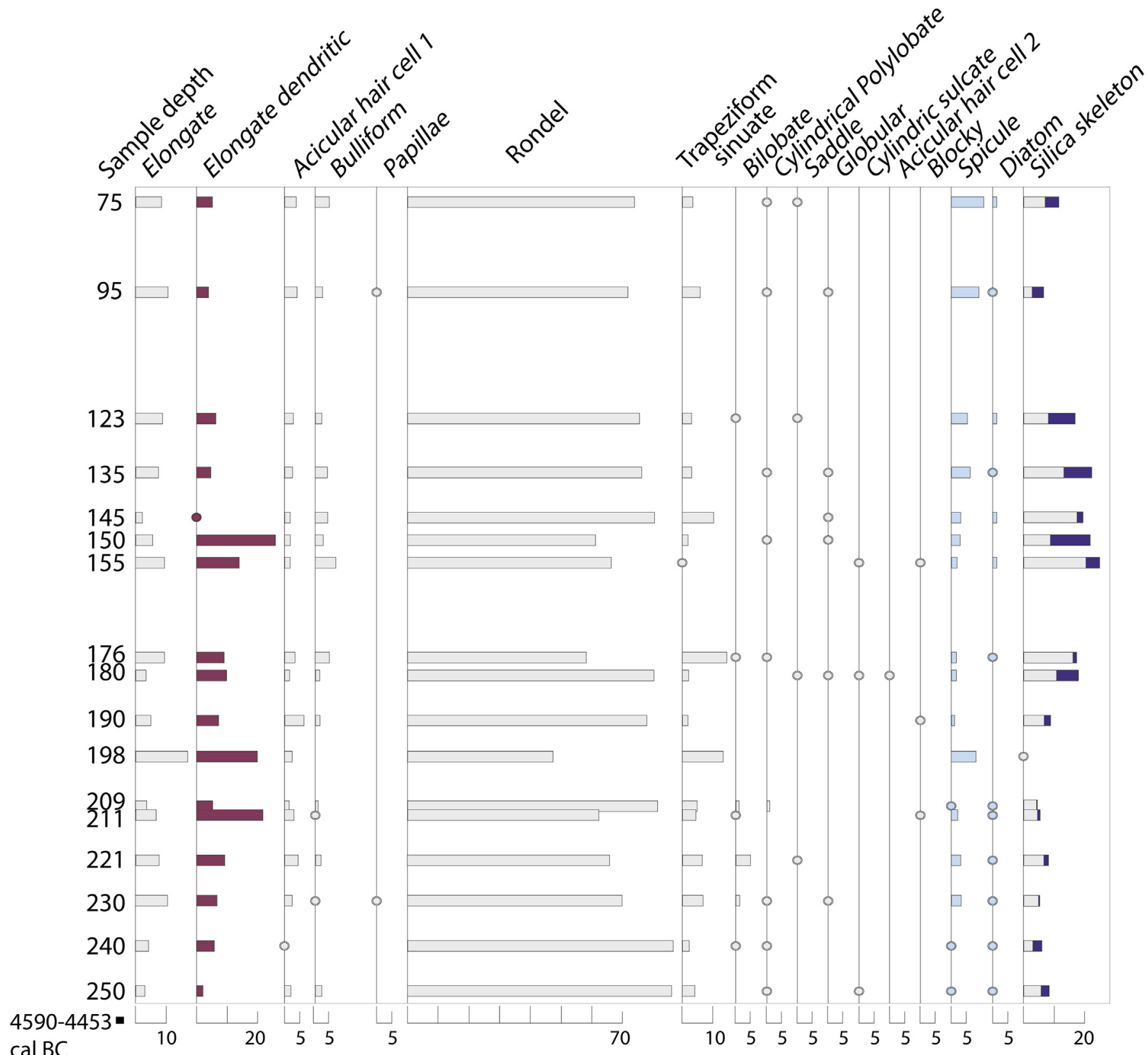

Fig. 5. Phytolith assemblages (\%) from core 12.

hulled six-row barley (Hordeum vulgare). Emmer (Triticum dicoccum) is also represented, but rarely. Additional economic plants possibly include Cornelian cherry (Cornus mas) and sloe (Prunus spinosa type), which could have been collected, but no other cultivated plants are recorded up to now. Unsurprisingly, coarse sieved samples did not produce any chaff remains. This will possibly change with the forthcoming study of fine sieved samples. Microwear analysis of lithic artefacts from the Taraschina site has recently shed new light on the hypothesis of crop husbandry practices because several sickle inserts have been identified, as well as a number of threshing sledge elements.

While no farming activities had been suspected up to now in the heart of the Danube Delta for pre- and proto-historical periods, the phytolith assemblages from Taraschina tend to show that Chalcolithic populations could grow cereals in this area. Cereal importation into the Delta by the Chalcolithic populations is possible. In the hypothesis of cereal importation, cereals should have been transported already threshed and processed (grains without straw). But, the hypothesis of local cereal cultivation is strengthened by the abundance of threshing by-products (and especially the high amount of silica skeletons coming from leaves and culms in both sequences), demonstrating that entire cereal plants were brought onto the site (with straw). Moreover, the identification of sickle elements tends to show that the cereal harvesting was probably done by people living in Taraschina.

The phytolith assemblages identified in Taraschina reflects the importance of the Pooideae subfamily. This group corresponds to wild temperate grasses, as well as $\mathrm{C}_{3}$ cereals. This taxonomical identification is in agreement with the cereals identified on the site from charred remains: Triticum dicoccum and Hordeum vulgare. Both of these species are the main cereals cultivated during the Gumelniţa Cultural period in the Romanian plain (Cârciumaru, 1989, 1996). The occurrence of frequent bilobate phytoliths in the lower part of the sequence is interesting because it could reflect wild grasses from the Arundinoideae or Panicoideae groups (e.g. wild Setaria or Phragmites australis), or the hypothetic presence of domesticated millet. Some seeds of broomcorn 


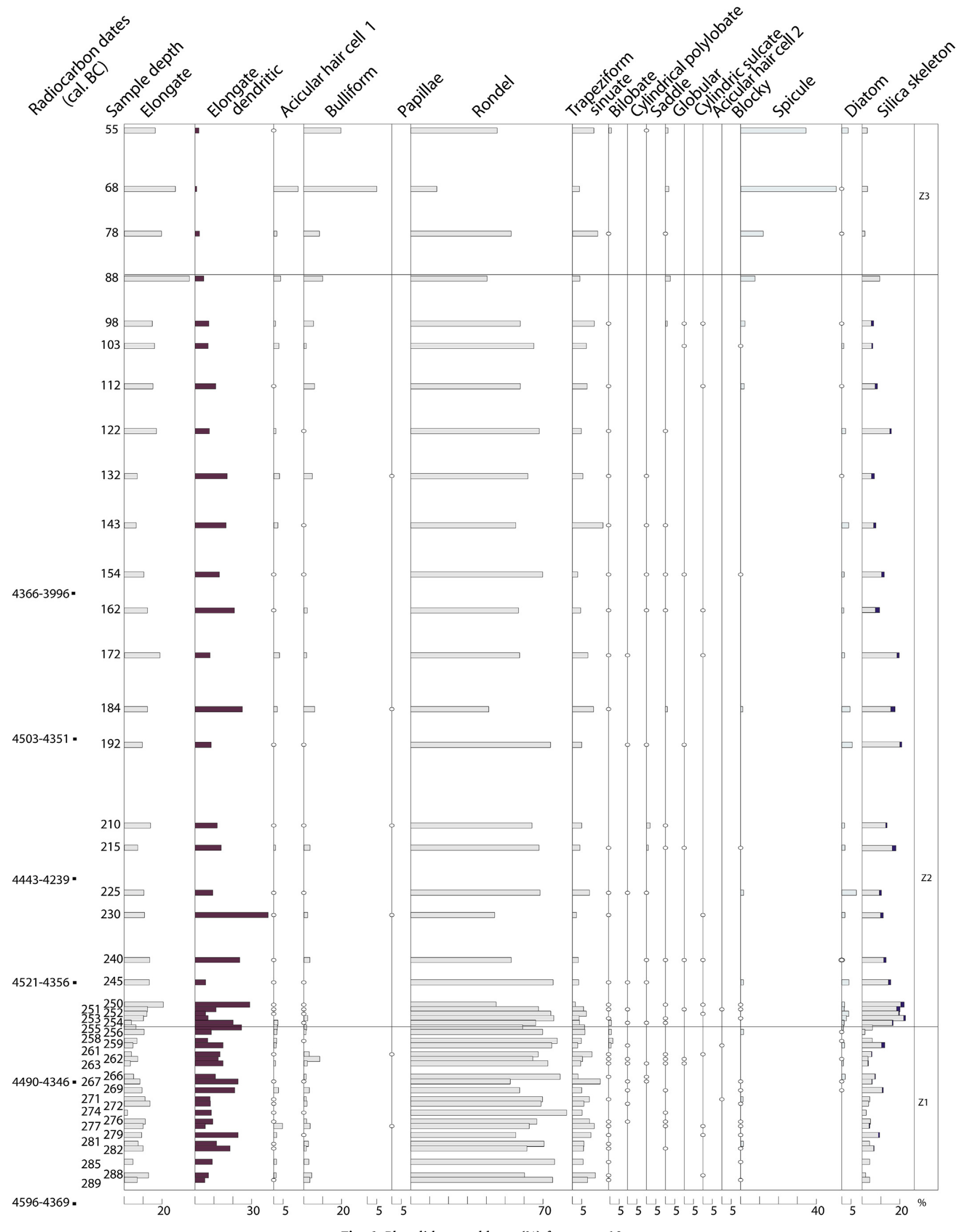

Fig. 6. Phytolith assemblages (\%) from core 10. 


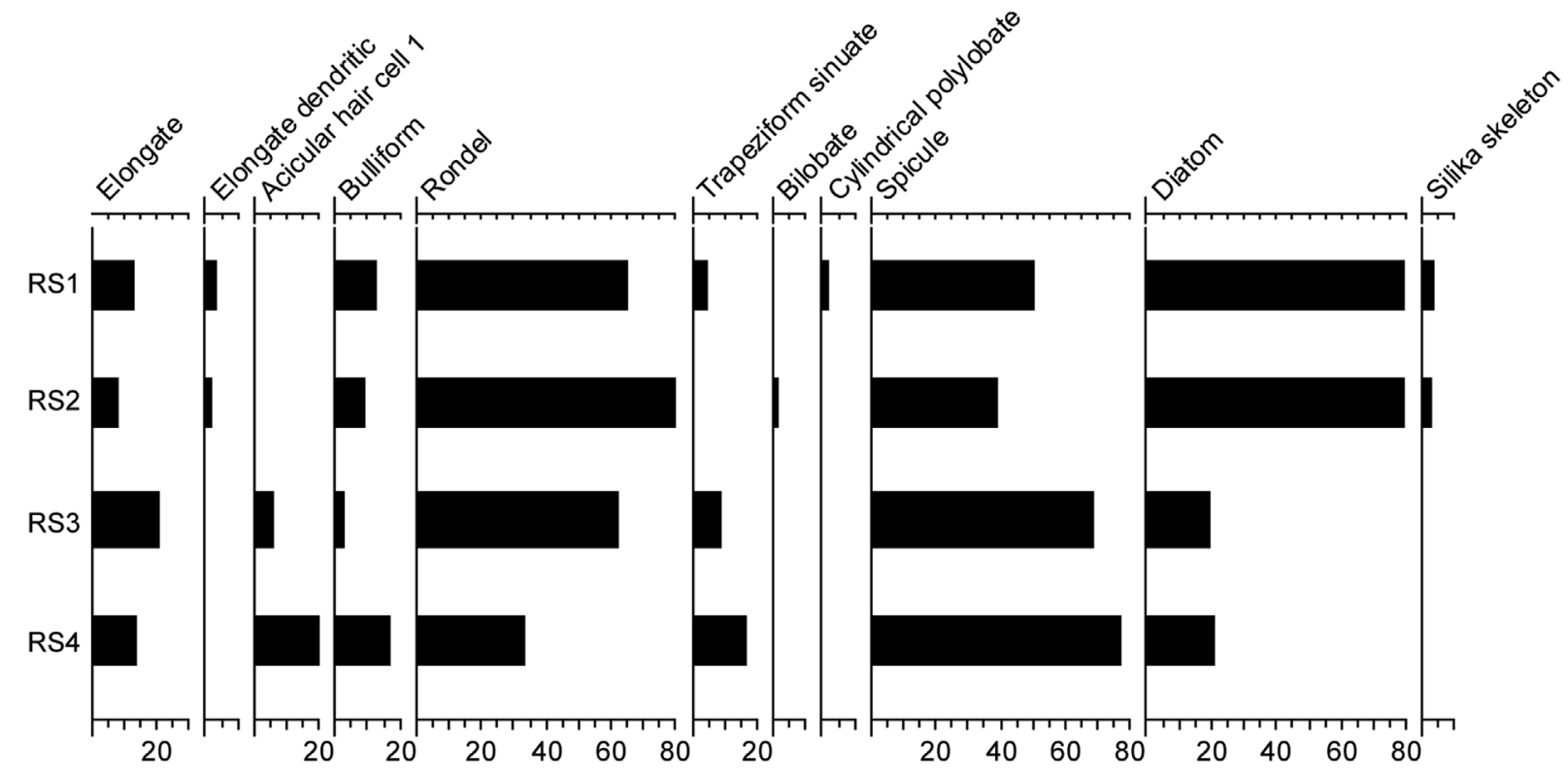

Fig. 7. Phytolith assemblages (\%) from reference samples.

(Panicum miliaceum) and foxtail millets (Setaria italica) have already been discovered in a Gumelniţa site, called Morteni, but the author is not convinced of the origin of the material (Cârciumaru, 1989). The beginnings of millet cultivation are still debated for Central and Eastern Europe (Hunt et al., 2008; Motuzaite-Matuzeviciute et al., 2013). But, broomcorn millet grains coming from old Ukrainian sites and recently ${ }^{14} \mathrm{C}$ dated, turned out to be significantly younger than the contexts in which they had been found (Motuzaite-Matuzeviciute et al., 2013). Thus, the question is not yet resolved in Eastern Europe. In Taraschina, the bilobate phytoliths may more likely come from wild Panicoideae or Arundinoideae.

\subsection{Interpreting phytolith assemblages recorded around the site}

Additional cores performed around the site (such as core 10) were initially intended for the palaeoenvironmental reconstructions of the Taraschina area. But, core 10 has yielded unexpected phytolith assemblages, more related to the site occupation, than to the natural environment of the site.

The phytolith assemblage from sequence 10 show significant similarities with the one coming from the archaeological deposits. In fact, many dendritic phytoliths, as well as silica skeletons (as many as $20 \%$ ) have been recorded in this off-site sequence. This pattern confirms that the lower and the middle deposits of core 10 reflect a strong human impact, resulting from the cereal processing practiced by the Chalcolithic communities. Although the sequence from core 10 was taken $40 \mathrm{~m}$ from the site, the phytolith content of the sediments shows that the human impact still prevails. A difference between both sequences is the lower values of silica skeletons coming from inflorescences in the off-site sequence (core 10). The phytolith assemblages from this sequence could reflect threshing processes, while the assemblages from the site support in addition the hypothesis of dehusking and winnowing processes on the site.

The rich phytolith deposits coming from the vicinity of the site, characterized by the signal of cereal processing, could have different origins: 1) This signal could correspond to a cropping area, where soils could be manured with domestic waste and/or dung. The dung could be composed of by-products of processing, used as fodder for cattle (Harvey and Fuller, 2005; Lancelotti and Madella, 2012). 2) Another possible hypothesis could be the presence of a huge threshing floor. The big amount of silica skeletons coming from culms and leaves can support this scenario. The hypothesis of a threshing surface, associated with the use of the threshing sledge (Tribulum) has already been proposed by Skakun for Chalcolithic sites in Bulgaria (Skakun, 1993; Anderson, 1998; Anderson et al., 2006). Several silica skeletons, displaying the characteristic scoring and break mark profiles of Tribulum process (Anderson, 2003, 2006; Anderson et al., 2006), have been observed in the Taraschina phytolith assemblages. 3) Since light chaff can be used as temper for construction purposes, to produce for example chaff-tempered clay (or daub) or mud-bricks (Hillman, 1984), the corresponding phytoliths could have been released after destruction and dissolution of building materials, and mixed with the surrounding sediments (Khedhaier et al., 2003). 4) The more parsimonious hypothesis to explain the large amount of phytoliths in the surrounding deposits, is that the cereal treatment on the site and its vicinity was intense, generating a large amount of threshing remains. These remains could have been used around the site by inhabitants (i.e. fuel, building, crafts, fodder; Anderson, 2003), or simply refused around the site.

The hypothesis that no occupation has been brought to light after $4100-4050 \mathrm{cal}$. BC is strengthened by the phytolith assemblages recorded in core 10 .

The analysis of the upper parts of core 10 reveals a gradual decline of the phytoliths characterizing cereal processing. Concurrently, the aquatic environment markers such as sponge spicules and/or diatoms show a significant increase, probably caused by hydrological variation. This situation is clearly reflected in the four reference samples (Fig. 7). The large amount of bulliform phytoliths, recorded in the upper part of core 10, could have different origins: i.) bulliform phytoliths are more frequent, because when plants experience an exceptional water-stress, such as high evapo-transpiration or flooded soils, they produce more bulliform phytoliths (Brémond et al., 2005; Messager et al., 2010). ii.) a part of bulliforms could have been produced by reeds (Phragmites australis), expanding at that time. So, the increase of bulliform type might indicate a variation of water level or/and probably an expansion of the reed bed in the site vicinity. This pattern appears to be simultaneous with the decrease of phytoliths characterizing cereal processing. Thus, the biogenic silica assemblages (phytoliths + sponge spicules + diatoms) indicate a significant environmental change in the Taraschina area, marked by the modification of the edaphic conditions around the site and the decline of human impact. As we can see in the reference samples, the reed formation developed nowadays in the heart of the Delta provides quite similar biogenic silica assemblages. Our results can 
be correlated with the sediment data, that show the development of a histosol along the last $100 \mathrm{~cm}$ of the sequence.

\section{Conclusion}

Phytolith assemblages have proved to be reliable markers to decipher human activities in the Danube Delta during the Chalcolithic period. Using this archaeobotanical proxy, it was possible to highlight an important signal of cereal processing on the site of Taraschina, and in its close vicinity. Massive presence of elongate dendritic phytoliths and silica skeletons provides evidence for crop processing on the site. This study, the first phytolith analysis conducted in the Danube Delta, suggests that Chalcolithic populations of Gumelniţa Culture could possibly grow cereal in the heart of the Delta, 6000 years ago. Following this, phytolith data indicate a gradual decline in phytoliths characterizing cereal processing and the simultaneous rise of aquatic environment markers. Archaeological data highlight a decrease of the anthropic signal around 4350-4250 BCE. Considering the close chronology of both events, the site of Taraschina could have been left due to rise of water and the resulting environmental change.

\section{Acknowledgements}

The authors would like to thank the anonymous reviewers for their helpful and constructive comments that greatly contributed to improving the final version of the paper. They would also like to thank the Editors for their generous comments and support during the review process. This research was partly founded by the project "Danube Delta Archaeology" directed by L. Carozza and supported by the "French Foreign Office" and the PN-II-CT-RO-FR-2012-1-0092 PHC Brancusi program coordinated by A. Burens and S. Ailincai. Phytolith analysis was conducted in the UMR 7264 CEPAM CNRS -Université Côte d'Azur (Nice).

\section{References}

Albert, R.M., Lavi, O., Estroff, L., Weiner, S., Tsatskin, A., Ronen, A., Lev-Yadun, S., 1999. Mode of occupation of Tabun Cave, Mt Carmel, Israel during the Mousterian period: a study of the sediments and phytoliths. J. Archaeol. Sci. 26 (10), 1249-1260.

Alexandre, A., Meunier, J.-D., Lézine, A.-M., Vincens, A., Schartz, D., 1997. Phytoliths: indicators of grassland dynamics during the late Holocene in intertropical Africa. Paleogeogr. Paleoclimatology, Paleoecol. 136, 213-229.

Anderson, P.C., 1998. History of harvesting and threshing techniques for cereals in the Prehistoric near east. In: Damania, A.B., Valkoun, J., Willcox, G., Qualset, C.O. (Eds.), The origins of agriculture and crop domestication (International Center for Agricultural Research in the Dry Areas, Aleppo, Syria), pp. 145-159.

Anderson, P.C., 2003. Observations on the threshing sledge and its products in ancient and present-day Mesopotamia. In: Anderson, P.C., Cummings, L.S., Schippers, T.K., Simonel, B. (Eds.), Le traitement des récoltes: un regard sur la diversité du Néolithique au présent, pp. 417-438.

Anderson, P.C., 2006. Premiers Tribulums, Premières Tractions Animales au ProcheOrient vers 8000 - 7500 BP ? In: Pétrequin, P., Arbogast, R.-M., Pétrequin, A.-M., van Willigen, S., Bailly, M. (Eds.), Premiers chariots, premières araires. La diffusion de la traction animale en Europe pendant les IVe et IIIe millénaires avant notre ère. vol. 29. pp. 299-316 CNRS Editions, Monographies du CRA.

Anderson, P.C., Georges, J.M., Vargiolu, R., Zahouani, H., 2006. Insights from a tribological analysis of the tribulum. J. Archaeol. Sci. 33 (11), 1559-1568.

Antipa, G., 1915. Wissenschaftliche und wirtschaftliche Probleme des Donaudeltas. Anuarul Institutului Geologic Al României VII, 1, București, pp. 88.

Antipa, G., 1941. Marea Neagră, Vol. 1-Oceanografia, Bionomia Si Biologia Generală a Mării Negre. Publicaţia Fondului Vasile Adamachi, T.X, LV, Acad, Română, Bucureşti, pp. 313.

Ball, T.B., Gardner, J.S., Anderson, N., 2001. An approach to identifying inflorescence phytoliths from selected species of wheat and barley. In: Meunier, J.D., Colin, F. (Eds.), Phytoliths: Applications in Earth Sciences and Human History. A.A. Balkema Publishers, Exton, PA, pp. 289-302.

Barboni, D., Brémond, L., Bonnefille, R., 2007. Comparative study of modern phytolith assemblages from inter-tropical Africa. Palaeogeogr. Palaeoclimatol. Palaeoecol. 246, 454-470.

Barboni, D., Bremond, L., 2009. Phytoliths of East African grasses: an assessment of their environmental and taxonomic significance based on floristic data. Rev. Palaeobot. Palynology 158 (1-2), 29-41.

Berlin, A., Ball, T.B., Thompson, R., Kittleson, D., Herbert, S.C., 2003. Ptolemaic agriculture, "Syrian wheat", and Triticum aestivum. J. Archaeol. Sci. 30, 115-121.

Blinnikov, M.S., Busacca, A., Whitlock, C., 2002. Reconstruction of the Late Pleistocene grassland of the Columbia basin, Washington, USA, based on phytolith records in loess. Palaeogeogr. Palaeoclimatol. Palaeoecol. 177 (1-2), 77-101.

Bozarth, S., 1992. Classification of opal phytoliths formed in selected Dicotyledons native to the Great Plains. In: Rapp, G., Mulholland, S. (Eds.), Phytoliths Systematics, Emerging Issues. Plenum Press, New York, pp. 193-214.

Brătescu, C., 1942. Oscilațiile de nivel ale apelor şi bazinului Mării Negre. Bul. Soc. Regale Geogr. LXI 1-112.

Brémond, L., Alexandre, A., Peyron, O., Guiot, J., 2005. Grass water stress estimated from phytoliths in West Africa. J. Biogeogr. 32, 311-327.

Carozza, L., Bem, C., Micu, C., 2011a. Société et environnement dans la zone du bas Danube durant le $5^{\text {ème }}$ millénaire avant notre ère. Editura Universităţii «Alexandru Ioan Cuza», Iaşi.

Carozza, L., Micu, C., Carozza, J.-M., Haită, C., Bălăsescu, A., Radu, V., Burens, A., Mihail, F., Ailincăi, S., Florea, M., 2011b. L'habitat Chalcolithique de Taraschina à Mila 23 et le peuplement ancien du delta du Danube durant la premiere moitie du 5ème millenaire avant notre ère. In: Mills, S., Mirea, P. (Eds.), The Lower Danube in Prehistory: Landscape Changes Ans Human Environement Interactions - Proceedings of the International Conference - Alexandria 3-5 November 2010, pp. 31-47 Ed. Renaissance, București.

Carozza, J.-M., Micu, C., Mihail, F., Carozza, L., 2012. Landscape change and archaeological settlements in the lower Danube valley and delta from early Neolithic to Chalcolithic time: a review. Quat. Int. 261, 21-31.

Carozza, L., Carozza, J.M., Messager, E., Danu, M., Burens, A., Micu, C., 2016. Landscape transformations and archaeological settlements in the upper Danube delta during early to middle Holocene: a palaeoecological insight. In: GEOREVIEW: Scientific Annals of „Ștefan Cel Mare” University, Special Issue: Central and Eastern Europe Paleoscience Symposium. From Local to Global 26(2), pp. 10.

Carozza, J.-M., Carozza, L., Radu, V., Levêque, F., Micu, C., Burens, A., Opreanu, G., Haită, C., Danu, M., 2013. Après le Déluge : évolution géomorphologique du delta du Danube après la reconnexion Mer Noire - Méditerranée et ses implications sur le peuplement énéolithique/chalcolithique. Quaternaire 24 (4), 503-512.

Cârciumaru, M., 1989. Étude paléobotanique pour les habitats néolithiques et énéolithiques de la Romanie. In: Palaeoethnobotany and Archaeology, International Work-group for Palaeoethnobotany $8^{\text {th }}$ Symposium Nitra-nove Vozokany, pp. 61-73 Acta Interdisciplinaria Archaeologica vol. II.

Cârciumaru, M., 1996. Paleoetnobotanica. Studii În Preistoria Si Protoistoria României (Agricultura Preistorică Si Protoistorică a României). Editura Bucovinei, Helios, Iaşi, pp. 201.

Coteţ, P., 1960. Evoluţia morfohidrografică a Deltei Dunării (O sinteză a studiilor existente şi o nouă interpretare). Probl. Geogr. VII 53-81 București.

Delhon, C., Alexandre, A., Berger, J.-F., Thiébault, S., Brochier, J.-L., Meunier, J.-D., 2003. Phytolith assemblages as a promising tool for reconstructing Mediterranean Holocene vegetation. Quat. Res. 59, 48-60.

Dimitriu, R.G., 2012. Geodynamic and hydro-geological constraints regarding the extension of the prospective archaeocultural area within the northern Romanian coastal zone. Quat. Int. 261, 32-42.

Fredlund, G., Tieszen, L., 1994. Modern phytoliths assemblages from the north american great plains. J. Biogeogr. 21, 321-335.

Ghenea, C., Mihăilescu, N., 1981. Palaeogeography of the lower Danube valley and the Danube delta during the last 15000 years. In: Starkel, L., Gregory, K.J., Thornes, J.B. (Eds.), Temperate Palaeohydrology. Wiley \& Sons, Chichester, pp. 343-363.

Giosan, L., Donnelly, J.P., Constantinescu, S., Filip, F., Ovejanu, I., Vespremeanu-Stroe, A., Vespremeanu, E., Duller, G.A.T., 2006. Young Danube delta documents stable Black Sea level since the middle Holocene: morphodynamic, paleogeographic, and archaeological implications. Geology 34, 757-760.

Harvey, E.L., Fuller, D.Q., 2005. Investigating crop processing through phytolith analysis: the case of rice and millets. J. Archaeol. Sci. 32, 739-752.

Hillman, G., 1984. Interpretation of archaeological plant remains: the aplication of ethnographic models from Turkey. In: van Zeist, W., Casparie, W.A. (Eds.), Plants and Ancient Man. Studies in Palaeoethnobotany. Balkema, Rotterdam, pp. 1-41.

Hunt, H.V., Vander Linden, M., Liu, X., Motuzaite-Matuzeviciute, G., Jones, M.K., 2008. Millets across Eurasia: chronology and context of early records of the genera Panicum and Setaria from archaeological sites in the Old World. Veg. Hist. Archaeobotany 17 (1), 5-18.

ICPN Working Group, Madella, M., Alexandre, A., Ball, T., 2005. International code for phytolith nomenclature 1.0. Ann. Bot. 96 (2), 253-260.

Khedhaier, R., Verdin, P., Furestier, R., Lemercier, O., Müller, A., 2003. Dépiquage au tribulum au Néolithique final dans le Sud-est de la France: indices convergents de la tracéologie et de l'analyse des phytolithes. Le cas du site de Forcalquier-La Fare (Alpes-de-Haute-Provence). In: Anderson, P.C., Scott Cummings, L., Schippers, T.K., Simonel, B. (Eds.), Le traitement des récoltes: un regard sur la diversité, du Néolithique au présent, actes des XXIIIe rencontres internationals d'archéologie et d'histoire d'Antibes, Antibes, 17-19 octobre 2002, pp. 477-493 Antibes, APDCA.

Lancelotti, C., Madella, M.M., 2012. The 'invisible' product: developing markers for identifying dung in archaeological contexts. J. Archaeol. Sci. 39, 953-963.

Lentfer, C.J., Boyd, W.E., 1998. A comparison of three methods for the extraction of phytoliths from sediments. J. Archaeol. Sci. 25, 1159-1183.

Liteanu, E., Pricăjan, A., Baltag, G., 1961. Transgresiunile cuaternare ale Mării Negre pe teritoriul Deltei Dunării. St. Cerc. Geol. 6 (4), 743-762.

Messager, E., Lordkipanidze, D., Delhon, C., Ferring, C.R., 2010. Palaeoecological implications of the Lower Pleistocene phytolith record from the Dmanisi site (Georgia). Palaeogeogr. Palaeoclimatol. Palaeoecol. 288, 1-13.

Micu, C., 2004. Neo-Eneoliticul în nordul Dobrogei în lumina cercetărilor de la Isaccea și Luncaviţa. In: Teză de doctorat, Institutul de Arheologie "Vasile Parvan" Bucureşti. Academia Română.

Micu, C., Carozza, L., Carozza, J.-M., Mihail, F., Jugararu, G., 2009. Observations sur 
l'habitat neo-eneolithique dans le Delta du Danube. In: Miscellanea in Honorem Annos LXV Peragentis Professoris Dan Monah Oblata. Romanian Academy Institute of Archaeology of Iași, pp. 317-336.

Mihail, F., Micu, C., Carozza, L., Carozza, J.-M., Groparu, T., Messager, E., Burens, A., Ailincăi, S., Danu, M., Mihail, C., 2014. „Dâmbul lui Haralambie” - un nou sit eneolitic în Delta Dunării. Pontica 47, 125-152.

Motuzaite-Matuzeviciute, G., Staff, R.A., Hunt, H.V., Liu, X., Jones, M.K., 2013. The early chronology of broomcorn millet (Panicum miliaceum) in Europe. Antiquity 87, 1073-1085.

Mudie, P., Mudryk, I., Gerasimenko, N., Rohozin, Ye, 2015. Palynology of the Danube delta and shelf - comparison of methods. In: 2015 GSA Annual Meeting, at Baltimore, Maryland, USA, 47(7), pp. 204.

Mulholland, S., 1989. Grass opal phytolith production: a basis for archaeological interpretation in the northern plains. Archaeobotany through phytolith analysis symposium, Annual meeting of the Soc. Amer. Archaeol. Abstr. Phytolitarian Newsl. 6 (1), 4.

Novello, A., Barboni, D., 2015. Grass inflorescence phytoliths of useful species and wild cereals from sub-Saharan Africa. J. Archaeol. Sci. 59, 10-22.

Panin, N., 1972. Histoire quaternaire du Delta du Danube, Essai d'interpretation des facies des depots deltaiques. Cercetări Mar. 4, 5-15.

Panin, N., 2004. The danube delta. geomorphology and holocene evolution: a synthesis. Geomorphologie: Relief, Proceesus, Paysage 9 (4), 247-262.

Pearsall, D.M., Piperno, D.R., 1993. Current Research in Phytolith Analysis: Applications in Archaeology and Paleoecology. University of Pennsylvania Press, Philadelphia.

Piperno, D., 1988. Phytolith Analysis: an Archaeological and Geological Perspective. Academic Press, San Diego.

Piperno, D.R., Pearsall, D.M., 1998. The silica bodies of tropical american grasses: morphology, taxonomy, and implications for grass systematics and fossil phytolith identification. Smithson. contribution Bot. 85, 1-22.

Portillo, M., Albert, R.M., 2011. Husbandry practices and livestock dung at the numidian site of althiburos (El Médéina, Kef governorate, northern Tunisia): the phytolith and spherulite evidence. J. Archaeol. Sci. 38 (12), 3224-3233.
Reimer, P.J., Baillie, M.G.L., Bard, E., Bayliss, A., Beck, J.W., Blackwell, P.G., Bronk Ramsey, C., Buck, C.E., Burr, G.S., Edwards, R.L., Friedrich, M., Grootes, P.M., Guilderson, T.P., Hajdas, I., Heaton, T.J., Hogg, A.G., Hughen, K.A., Kaiser, K.F., Kromer, B., McCormac, F.G., Manning, S.W., Reimer, R.W., Richards, D.A., Southon, J.R., Talamo, S., Turney, C.S.M., van der Plicht, J., Weyhenmeyer, C.E., 2009. Radiocarbon 51, 1111-1150.

Romanescu, G., 2013. Geoarchaeology of the ancient and medieval Danube Delta: Modeling environmental and historical changes. A review. Quat. Int. 293, 231-244.

Rosen, A.M., 1992. Preliminary identification of silica skeletons from near eastern archaeological sites: an anatomical approach. In: Rapp, G.R., Mulholland, S.C. (Eds.), Phytolith Systematic. Plenum Press, New York, pp. 129-147.

Runge, F., 1999. The opal phytolith inventory of soils in central Africa quantities, shapes, classification and spectra. Rev. Palaeobot. Palynology 107, 23-53.

Skakun, N.N., 1993. Agricultural implements in the neolithic and Eneolithic of Bulgaria. In: Anderson, P.C., Beyries, S., Otte, M., Plisson, H. (Eds.), Traces et fonction: les gestes retrouvés. ERAUL 50, Liege, Belgium, pp. 361-368.

Strömberg, C.A.E., 2002. The origin and spread of grass-dominated ecosystems in the late Tertiary of North America: preliminary results concerning the evolution of hypsodonty. Palaeogeogr. Palaeoclimatol. Palaeoecology 177 (1-2), 59-75.

Stuiver, M., Reimer, P.J., 1993. Extended 14C data base and revised CALIB 3.0 14C age calibration program. Radiocarbon 35, 215-230.

Twiss, C., Suess, E., Smith, R., 1969. Morphology classification of grass phytoliths. Proc. Soil Sci. Soc. Am. 33, 109-115.

Vasiliu, I., 1995. Cercetări arheologice în Delta Dunării. Mormintele cu ocru de la ChiliaVeche. Peuce XI 49-87.

Vâlsan, G., 1934. Nouvelle hypothese sur le Delta du Danube. Comptes rendus Congrès Int. Géogr., Varsovie, II 342-355.

Vespremeanu-Stroe, A., Zainescu, F., Preoteasa, L., Tătui, F., Rotaru, S., Morhange, C., Stoica, M., Hanganu, J., Timar-Gabor, A., Cârdan, I., Piotrowska, N., 2017. Holocene evolution of the Danube delta: an integral reconstruction and a revised chronology. Mar. Geol. 388, 38-61. 